\title{
NEW LABOUR: A WITNESS HISTORY
}

\begin{abstract}
This article is the edited transcript of a witness history seminar which brought together high profile 'insiders' and 'outside' academic commentators to reflect critically on New Labour's governance of Britain, 1997-2010. The contributions cover major areas of government activity, notably the economy, industrial policy, social justice, energy policy, 'Europe', military intervention, the use of intelligence and government decision-making. In their respective area of expertise, the contributors investigate the Conservative legacy seen through the eyes of New Labour people, the policies New Labour under Tony Blair and Gordon Brown tried to put in place, what changes these policies were intended to bring about and, finally, what the overall balance sheet of achievements was. The concluding section draws out the key domestic and foreign policy lessons learned during the New Labour years. The article presents a fascinating collection of findings that will be hugely relevant to Ed Miliband's Labour Party as it gears up for the 2015 general election and after.
\end{abstract}




\section{NEW LABOUR: A WITNESS HISTORY}

This article is an edited transcript of a witness history seminar held on 27 March $2013 .{ }^{1}$ The aim of the workshop was to bring together 'insiders' who had worked in the New Labour governments of Tony Blair and Gordon Brown to share experiences and interpretations with academic 'outsiders' specialising in the study of New Labour's governance of Britain with a particular view to drawing out lessons for the post-New Labour Party of Ed Miliband as he refashions the party in the lead up to the 2015 general election. All the insiders acted as special advisers to key New Labour people, including the prime ministers themselves, giving us a different dimension and wealth of insight into New Labour than generally has been the case in accounts of this volatile period in contemporary British history. We were very grateful for their input, and for allowing us to publish their reflections on the New Labour years here.

Given that the event lasted one day, it was clearly impossible to cover each and every dimension of New Labour's governance of Britain domestically and internationally. Some of the key themes that unfortunately had to be left out were education and health policy, policing and crime, immigration and the evolution of the UK's relationships with key international state, non-state actors, and international organisations. That said, we aspired to cover some of the most telling areas of government activity, with a particular focus on contentious policies that caused New Labour significant dilemmas, or which stimulated political debate between the (now three) main political parties in the UK. We especially wanted to assess how New Labour sought to market itself apart from 'Old' Labour, and then to position itself as a credible party of government by devising policy platforms and branding for a suite of policies aimed at 'modernising' the British political economy and role in the world at the turn of the twenty-first century. We were interested both in the construction of New Labour as a political programme as well as the various component policies that fed its self-image and grand narrative about its place in British politics and the wider world.

Each speaker was given ten minutes to stimulate discussion by addressing the following broad themes. First, what did New Labour try to achieve, and how, in the policy area or areas under consideration? Second, what was the overall balance sheet of achievements 1997-2010? Finally, what 
lessons can be learned for the Labour Party today? Below is the edited record of the pre-prepared remarks, with clarifications added where necessary in the notes. The edited version sticks faithfully to what was said on the day, and has only been shortened to meet the word length for this journal. All contributors were shown the edited transcript prior to publication. As with the workshop itself, the contributions below are split into 'domestic policy' and 'foreign policy'. In domestic policy the emphasis is on the economy, social justice, industrial relations and energy policy. In foreign policy speakers concentrate on 'Europe', the use of force and the intelligence services.

\section{Domestic Policy}

\section{Dan Corry}

I'm an economist and I worked at the Treasury as a civil servant in the 1980s, and then I worked at the Institute for Public Policy Research (IPPR) for some of the 1990s, having worked for the Labour Party on economic policy in 1989 to 1992 . I was Special Adviser for most of the Labour years and I'll give an overview of what I think we were trying to do on the economy, what we did, whether it worked, why it didn't work, and what one learns from it. ${ }^{2}$

To begin with, it is important to point out that the UK economy in 1997 was recovering, but it had had a very, very bumpy ride over the previous twenty to thirty years, with ups and downs all over the place and inflation out of control. A further issue was that Labour had a reputation for screwing up the economy, basically, and so there was a real nervousness that we would come in and everything would go wrong. I do remember some of the worries in the run up to the 1997 election, for instance that the pound would collapse and push up inflation. These fears explain some of the behaviours that came later. The main myth I want to counter today is that New Labour pursued a neo-liberal approach to economic management - very light touch to encourage growth; protect the financial sector; to tax them and use that money for public services. I don't think that's what we were trying to do, it's too simplistic. It's this myth I will challenge today by suggesting that if you look at the whole plethora of policies that Labour brought in, they were all about trying to change the nature of the way in which our economy works, moving it in a social democratic direction. Sometimes people focus too 
much on the one 'big thing' you did. However, as a Special Advisor in different departments I felt it just as important that every day, if we made decisions in a slightly more progressive way than they would otherwise have been made, then it all added up to something. And I think that is true when we consider New Labour's record on the economy.

To begin with, let's reflect on the changes we made. I concentrate on the micro side because on the macro side, such as Bank of England independence, the New Labour story is better known. First and foremost there was interference with a key building block of the market economy aimed at changing the external structures within which company decision-making took place. There were quite a lot of changes in the way companies behave, in terms of the climate of corporate governance. There was a big review of company law which did produce some changes in the way it dealt with empowering shareholders, in terms of directors' pay, and so forth. There was a much tougher competition policy which ratcheted up enormously in the first few years in particular. There was change in the way companies dealt with the labour market especially via re-regulation of the labour market, the minimum wage being the most obvious but not the only innovation. Prime Minister Tony Blair at the time wanted to emphasise that we were still very flexible relative to everybody else, which was true, but nevertheless there was an awful lot of stuff including making union recognition easier and changing the unfair dismissal rules. So, that changed the context in which firms work. In addition there was an awful lot done on the skills, training and education side. Consistently through these manoeuvres, New Labour policies sought to emphasise the importance of government in underpinning whatever the private sector was going to do. There was an awful lot of work on infrastructure of different types. There was a massive increase in investment in science. There was quite a lot done on communications, for example 3G licenses. There was quite a lot on the energy side (see Geoffrey Norris, below), on carbon, and even on rail, where I spent a happy year of my life trying to turn round Network Rail.

The flip side of that was a tradition that brought in quite a lot of 'new economy' thinking, not least during Peter Mandelson's brief period in what I call 'Mandelson 1' when I worked for him at the Department of Trade and Industry (DTI). ${ }^{3}$ The aim there was to try to attract US enterprise and venture capital kind, because in Britain all the statistics showed at the time how few people wanted to 
be entrepreneurs: parents never wanted their kids to be entrepreneurial because it was hard to get hold of capital. A lot was changed on that. There was the move to the Regional Development Agencies (RDAs), and there was an attempt at one point to create an elected tier of the RDA in the North East, but the election was lost and that whole agenda went. ${ }^{4}$ But nevertheless, there was a certain degree of decentralisation of economic decision making and power via public-private partnerships to improve delivery, some of which are notorious - and some Private Finance Initiative (PFI) projects which were pretty terrible, some of which were very successful. In sum, on the micro side, New Labour sought to shift the incentives faced by private sector decision-makers quite substantially.

Did all those things work? Well, I would say in many ways they did work. I co-authored a paper in 2011 with Anna Valero and John Van Reenen looking at productivity, growth and jobs in the New Labour years and, even if you take out financial services, it shows productivity was very good relative to the main competitor countries. ${ }^{5}$ There is an argument in the academic world as to whether all of this was just an outcome of the Margeret Thatcher reforms [1979-1990] because you see the trend changing around then and, in a sense, Labour continued that trend rather than completely changing it. However, I think most people argue that those reforms would have run out of steam if Labour hadn't done anything. Plus, if you are even more sceptical, you could at least say 'at least Labour didn't reverse that trend'.

So, on productivity the New Labour record was positive. If you look at most of the aggregates - and I am talking up to 2008 when the global financial crisis hit - they were similarly encouraging. On employment, trade and so on: most of the outcomes were pretty good. Equity was okay-ish in terms of what was happening to Gini coefficients, ${ }^{6}$ not least if you look at what had been happening in the period before New Labour came to office. The trend towards greater inequality was not reversed but it was stabilised. Now, people are interested in the 'squeezed middle' but in the New Labour years we were not focused on this and it was felt that people were generally getting better off. Being Labour people, we have a great tendency to say 'it was all a disaster', even the Labour government did, and I think the evidence is absolutely exactly the opposite. It was, it was a very, very successful period. 
Now to the negatives, or what went wrong, and when Lehman Brothers collapsed and we get a banking crash I think that showed first of all that in banking regulation we got it woefully wrong. ${ }^{7}$ Having said that, I think everybody got it wrong - it's hard to look across the world and see any government that was getting it particularly right. You can identify countries which had less severe problems but that was often to do with the nature of their banking industry. So, for instance, Canada survived better and everyone was hoping that Mark Carney would bring some of his magic over to Britain as Governor of the Bank of England [from 1 July 2013] - the 2011 budget bascially said, 'over to you, Mark Carney' in terms of economic growth. Banking policy was clearly a massive, massive mistake and one has to think about why that happened, why we got it wrong and why everybody got it wrong. In some of the other areas I've talked about there were weaknesses too. Skills is a very good example - the whole Leech agenda, Train to Gain and the attempt to get training up didn't work, and maybe we didn't change tracks quick enough. In some areas we weren't bold enough and I think there was always a desire in the New Labour years - I suspect there always will be, particularly for the Labour party - to sustain a relationship with business, which is always a bit tricky. Hence, in retrospect, we bottled trying to implement certain changes because we didn't want too many fights on too many fronts with the Confederation of British Industry $(\mathrm{CBI})$ at the same time.

Added to this, the other thing that emerged post 2008 is that we let the fiscal deficit rise too high given where the economy was. I don't think that was obvious at the time, only in retrospect. If you look at what the structural deficit, nobody was screaming about it, it wasn't deemed to be particularly big. But knowing what we know now we should have, in the good times, built up a surplus to see us through lean times. That said, when the crash happened I think we didn't do too bad a job. People say we should have moved faster in sort nationalising Northern Rock and so forth but this was unchartered territory - we really didn't know what the hell was going on - and we moved pretty fast pretty well. ${ }^{8}$ Furthermore, if you look internationally I think most people would agree that the aftermath of the crash saw one of Gordon Brown's strongest features coming through - he's got a lot, a lot of weak features - but one of his strongest features was that he sees the world in international terms and he was very strong on trying to get the G8 and the G20 into taking action. I am afraid, with him gone and with some of the other characters gone, there has been very, very little international 
coordinated action which has been a real problem for the world. Finally, in terms of the UK real economy the government was pretty active in terms of what happened with repossessions, business failures and so on. They were surprisingly few. We let automatic stabilisers play out, we created the National Economic Council [in October 2008]. By 2010 there was a degree of growth back in the economy actually; it wasn't all doom and gloom. Despite what the current government might say about its economic 'inheritance' in 2008 we were back to growth in 2010. I don't think it was a bad effort.

So, what are the lessons that I take from all of that? I think the number one thing is that running Britain, which is a relatively small open economy with globalised trade, capital flow, labour, home to a public who are a bit tax resistant, to put it mildly, is not easy; there are limits on what you can do. Having said that, I think at times we were probably not brave enough. If a future Labour government believes it has got the analysis right and it feels a policy is the right thing to do, sometimes you've got to be a bit harder on taking on some of the interests arrayed against you. It is a question of political management: how do you produce enough coalitions, and enough of the right sort, to support you?

The second lesson is on the supply side. There is a great argument at the minute about what you should do when you come into power on macro policy, how quickly you reduce the deficit and so on. But, in the long run, it is the supply side that really matters, and a lot of these things take an awful long time. Somehow you need to bring in institutions that have got genuine bite over the long term. And there has been a lot of continuity with the coalition. There's been a lot of change, but in some things, like industrial policy, maybe that's because it's Vince Cable rather than anybody else there's been a good deal of continuity with the New Labour approach. In terms of infrastructure and getting government clearer on its priorities and moving towards underwriting risk and so forth, there is some consensus. At times, governments come in and scrap things just because they were in opposition and they were committed to scrapping it; that approach is a bit daft.

My final lesson is therefore about the politics of opposition. People have said that one of the problems with the New Labour governments was that we didn't set up enough institutions, that we didn't have enough popularity to last across a change of government, which I think is too easy to say. 
A lot of things we implemented, opposition parties and civil society have embraced, for example, I think it is extraordinary that the minimum wage is not controversial anymore. The business community cries out for certainty and not having governments overturn things every time governments change is one way of reducing economic uncertainty. Thank you.

\section{Geoffrey Norris}

I was Special Advisor in the Prime Minister's Policy Unit and at the Department for Business for the thirteen years when New Labour was in government. Before that, I'd worked for Tony Blair when he was Leader of the Opposition and I'd also worked for Robin Cook for a number of years. I went from Number 10 to work at Business when Lord Mandelson returned from Brussels to become the UK Business Secretary. I want to look at the politics of energy and industrial policy, and also to try and say something about how New Labour thinking evolved throughout the thirteen years of being in government. My argument is that energy and industrial policy were areas where New Labour, before 1997, can probably be described as being relatively policy light but ended up, particularly towards the end of its thirteen years in government, becoming more active and more interventionist. I want to look at the cause of that shift and what that might mean for today's Labour Party.

To begin with, why were we policy light before 1997? Essentially New Labour was a response by the Labour party to the way that the policy environment had changed after 1979. First of all, you had seen the ascendency Margaret Thatcher's government and the growth of neoliberalism. Now, I think it's questionable how far Mrs Thatcher reshaped the role of the state in public services and welfare but I think she absolutely did reshape the role of government in the management of the economy. There were many privatisations and market liberalisation, as in energy and telecommunications, and there were huge cuts in government expenditure on industrial support and regional support. You had Nigel Lawson, when Energy Secretary, famously announcing there was no such thing as energy policy. So, Mrs Thatcher and neoliberalism were an immensely powerful force in reshaping the policy environment.

There was an internal Labour Party dimension to all that, which was expressed in a desire to put as much distance as possible between New Labour and its perceived failed past of economic 
mismanagement, of picking 'winners', of incomes policies, and of excessively powerful trade unions. The perceived imperative for New Labour was to show that we had turned a new leaf on the economy, that we weren't hostile to business, that we were pro-competition, and that we didn't hanker after state intervention. The reason we were desperate to do this was because voters believed we cared and consistently throughout the 1980s and 1990s people basically thought Labour was the best party on the health service, best party on education, but actually this counted for not that much when set against the economic picture. They didn't think that we could be trusted to run the economy, that we were going to tax and spend and that we were going to run excessive deficits. So, the key to victory in 1997 was to establish our economic credibility, our economic competence. We did in large measure by becoming policy light so that we didn't have policies that were going to cause controversy or unease amongst business commentators, and by sticking to emitting central macro-economic messages about stability and no longer being a tax and spend party.

New Labour wasn't entirely policy blank on energy and industrial policy. We talked about public private partnerships, infrastructure and science and technology. There were some what are called horizontal, cross business policies that we talked about in opposition, in particular competition. But we certainly didn't talk about central policies for particular sectors of British industry because that was seen as too interventionist. We were committed to developing Regional Development Agencies (RDAs), which Dan has spoken about [see above]. We talked a lot about skills and human capital. Some of you may remember something called the University for Industry which, as Shadow Chancellor, Gordon Brown wanted to use to solve every single problem! Sadly, when were in office, this proved to be very much a mouse of a policy.

Although we were policy light, however, we were hyperactive on engaging with business and we had a sustained campaign to reassure people that we wouldn't increase the top rate of income tax. Having been much involved in the campaign before 1997 to engage with business, the collective sigh of relief from the business community when Tony Blair and Gordon Brown announced we weren't increasing the top rate of income tax was enormous. It is extremely important to bear in mind that business people, when they are expressing an opinion about political parties, are actually expressing an opinion more often about their wallets than they are about the general state of the economy! 
In office from 1997 I am going to argue there were essentially two phases to the New Labour years on energy and industrial policy. The first and longest phase, about the first two thirds of New Labour, saw the complete liberalisation of markets so that households could choose their suppliers and we confirmed the reduction in the role of the state. We had one policy swerve which was when we suddenly realised that in a liberalised marketplace it was unlikely that generators would buy extremely expensive British mined coal and we introduced a moratorium on building nuclear fired gas stations. But that was short lived and once we got over that we continued with market liberalisation, creating one of the most, if not the most, liberalised energy markets in the world - for good or bad. On industrial policy, during the first few years of New Labour we were extraordinarily prudent on public expenditure and we basically kept very closely to the previous government's expenditure plans, which had themselves been quite tight. Even had we been policy heavier regarding industry, we would not have had the money to do it.

All of that said we did create RDAs, we provided fairly regular dollops of money for the aerospace and car industry, while science based spending was increased very substantially. We very significantly reformed and toughened competition law in this country. And there were numerous 'peashooter' scale policy initiatives, policy schemes which, looking back, were more about press opportunities than policy change if I am absolutely candid. Crucially, for much of the time, it didn't really seem to matter that we didn't have a more active industrial policy because actually the UK's economic performance was extremely good in terms of employment levels and growth rates. We were continuing to narrow the productivity gap between the UK and the other G7 economies. So, although we didn't have a very active industrial policy, what did it matter?

The one exception to this good news story of the UK under New Labour pre-financial crisis was manufacturing. The UK wasn't unique in seeing its manufacturing sector decline but, when I look back on it, I would have to admit that it appears the decline in the UK during this period was atypically sharp. Manufacturing led GDP was $20 \%$ when we came into office; pre-financial crisis it had shrunk to $11.3 \%$, and when you look at the employment levels, that contraction was even more stark - down from 4.2 million to 2.6 million. Why this sharp downturn in manufacturing? Essentially, after Britain exited the [Exchange Rate Mechanism] in the early 1990s [September 1992] there was a 
period of devaluation. But from the mid-1990s, the pound started rising. In the mid-1990s the PoundDeutschmark exchange rate was 2:20; by the summer of 1997 the Pound-Deutschmark exchange rate was 3; and then by year 2000 it had gone up to 3:40. We had always thought the danger was that there would be a Labour government and the Pound would plummet. As it was, it continued to rise and it rose to a level where UK manufacturing became seriously uncompetitive. Simultaneously, the effect of a high Pound was ambiguous because it significantly reinforced the UK as a location for financial services, which rather too our eye off the ball of the squeeze on manufacturing.

The second phase covers roughly the final third of Labour's thirteen years - was the period of the change. In energy, what happened was that a policy previously driven by liberalisation and competition became more complicated in that that we needed to tackle climate change, reduce carbon, and deal with concerns about energy security. Over the last 18 months of the New Labour governments we effectively started reviewing energy policy in quite a big way and a consensus emerged that, basically, the role of the state and the market needed to be recast. And that process of energy policy review essentially became the coalition government's energy market reforms. Indeed, the coalition government's energy market reforms are incredibly interventionist, with a much more active role for the state.

In industrial policy the tipping point was the financial crisis, which was slow-burning but suddenly erupted to put us on the edge of a precipice. Gordon Brown did a number of significant things internationally and also drove the UK government to intervene. Industrial policy was transformed because we were searching for any policy lever that we thought could make a difference and things that previously had been regarded as being, beyond the pale were suddenly deemed worth trying. This was reinforced when Peter Mandelson returned from the European Commission to the UK Business Department, ${ }^{9}$ instigating a new activism in industrial policy. There were lots of initiatives, including a big car scrappage scheme, while anything 'green economy' attracted state money. We also began asking some quite serious questions about the UK mergers and acquisitions regime. This new industrial policy agenda was work in progress when the electorate in its infinite wisdom decided to have a change of government in 2010. But was it working? It is quite hard to judge, even in hindsight. Would it have worked? It's equally hard to say. However, key planks of 
that agenda have been reinvented as the coalition has desperately sought out anything that might fuel growth.

To conclude, the new activism wasn't a return to the wisdoms of Old Labour. It wasn't about public ownership, it wasn't about planning - I mean we weren't talking about creating a national economic development office - but I we were willing to talk about strategies for sectors, which was rather heretical to many in the civil service at the time. It reflected instead a more positive role for the state than we had perhaps envisaged in 1997, and increasing scepticism for market solutions. In terms of the future, Ed Miliband's 'new New Labour' seems pretty unclear on activism and industrial policy. Ed will tell you how they don't particularly like to refer to themselves as new New Labour, but whatever it is they are, whatever it is they feel comfortable with describing themselves as, I think it is still slightly ambiguous because it's not some of the old collectivist verities of public ownership moving towards planning. It is not, though, a kind of sub-neoliberalism, which New Labour in many ways was pre-1997. Thank you.

\section{Patrick Diamond}

I'm going to talk about social justice, making three sets of comments. The first relates to what New Labour meant by social justice; the second concerns what the empirical evidence tells us about how Labour performed in relation to some key dimensions of social justice during its 13 years in office. And then, finally, I will draw out a few lessons learned for future policy. 1

Let's start with what New Labour meant by social justice, by comparing that with what Old Labour meant by social justice. ${ }^{10}$ Now, in doing that, I am very conscious that one is entering into the kind of crude binary categorisation between old and new which I have spent quite a lot of my time arguing against. But, nonetheless, on the whole I think it is an interesting conceptual device and I think in different ways politicians like Tony Blair and Gordon Brown spent a lot of time consciously

${ }^{1}$ The core ideas and data on which this talk is based draw on J. Hills, Inequality and the State, Oxford: OUP, 
defining themselves as being New Labour and not Old Labour; so, to some extent, the juxtaposition works. I would say that Old Labour's view of social justice was based on four very broad principles. One was a commitment to redistribution and some notion of equality of outcome. The second element was a notion of 'fair shares'. The third element was a commitment to the abolition of poverty, which was a very strong element of the 1945 government's programme and enhanced in key respects by the Labour governments of the 1960s and 1970s. The fourth element was about delivery - the idea of the central state as being the key leading agent of social justice ${ }^{2}$.

So, that's Old Labour. I think it is possible to posit four very broad elements of what New Labour meant by social justice. ${ }^{11}$ The first was a commitment to the idea of equality of opportunity and not just outcomes. This meant, therefore, a policy approach characterised not just by transfers through tax and benefits but also investment in various kinds of public services. This was intended not just to improve the equality of economic outcomes but to improve access to opportunities, particularly for sections of the population who were experiencing significant deprivation. A second core element was the notion of 'rights and responsibilities', which insistedargued that those sections of society that did experience significant relative deprivation had to accept some responsibility for their situation, and that, if they were going to be in receipt of certain kinds of state benefits, then they had to exercise certain obligations to the state in return for those benefits. The third element was a commitment to a discourse about social exclusion and social inclusion, going well beyond a commitment to abolishing a certain type of material poverty ${ }_{-}^{3}$ The final element, juxtaposed perhaps somewhat crudely with the Old Labour view of the central state as the instrument of delivery, was that New Labour had a view of delivering certain kinds of social justice policies which didn't just rely on the central state, but which involved a certain degree of devolution of power, an element of decentralisation. This entailed a commitment to institutional innovation, including from 1997 the

${ }^{2}$ G. Mulgan, 'Going Against the Grain: Social Policy Since 1997', in W. Paxton \& N. Pearce, Social Justice: Towards a more Equal Society, London: Politico's, 2005. 
Social Exclusion Unit and other attempts to create agencies that would oversee different approaches to social justice policy and poverty alleviation ${ }^{4}$.

On the empirical trends, the place to start is with the context of New Labour's economic inheritance. In 1997, the UK had among the worst poverty rates in the developed state economies for children and for pensioners ${ }^{5}$. Next, after 1979 , there was growing- polarisation in the incomes of people in work and those households without work, a growth in pockets of long-term unemployment and, within that, a growth in significant kinds of spatial and area based inequality. Part of that was an entrenchment of the north-south divide. Furthermore, New Labour inherited an economy in which the wages of the low skilled were declining sharply. That was clearly a facet of changes within global labour markets and the international division of labour but was also a consequence of certain kinds of deregulatory policies imposed by the post-1979 Conservative governments ${ }^{6}$.

Surprisingly perhaps, the policy mix which New Labour pursued after 1997 looked quite Old Labour when you actually look at the range of different initiatives that the government pursued. It introduced the national minimum wage [National Minimum Wage Act 1998, coming into effect April 1999]; it brought in the New Deal [1998; renamed Flexible New Deal in October 2009] which was intended to deal with long term unemployment and youth unemployment; there was significant investment in tax credits which were particularly targeted at child poverty and pensioner poverty; there was the creation of the Child Trust Fund [from January 2005] intended to help poorer families to enable those families to have assets for their children which otherwise only richer families might have. I also looked at some of the numbers around the extent to which the Labour governments redistributed through services and through directing public expenditure at poorer areas. One of the things that the New Labour government did very aggressively was to practice a 'prioritarian' approach to public services. On the National Health Service (NHS) and schools, there was a considerable weighting of expenditure towards hospitals and schools in the poorest areas. In addition to these tax and benefit decisions, the New Labour government was prepared to increase National

${ }^{4}$ G. Mulgan, 'Going Against the Grain: Social Policy Since 1997', in W. Paxton \& N. Pearce, Social Justice: Towards a more Equal Society, London: Politico's, 2005.

$5 \mathrm{~J}$. Hills, Inequality and the State, Oxford: OUP

6 J. Hills, Inequality and the State, Oxford: OUP 
Insurance contributions in 2002 to pay for improvements in the NHS. It introduced new kinds of taxation on pension funds; it introduced a levy on privatised utilities; it introduced new forms of stamp duty on homes; and between 1997 and 2007 tax as a proportion of GDP in the UK increased from $39.3 \%$ to $42.4 \%$, which is one of the largest increases within the industrialised countries in that $\operatorname{period}^{7}$.

What was the upshot of these initiatives? The headline is that there was significant progress on poverty but less progress in relation to income inequality. Studies have shown there was a very impressive fall in child poverty and pensioner poverty. In fact, the fall in child poverty and pensioner poverty was the sharpest fall in poverty in the post-war period $\stackrel{8}{*}$. By contrast, the performance on poverty for adult households without children was much less impressive and one has to remember that caveat in relation to the government's record on poverty reduction. On inequality the performance was clearly less impressive, and there was very little change in the Gini coefficient between 1997 and 2010 [see Dan Corry, above]. New Labour certainly succeeded in halting the rise in inequality that had occurred between 1979 and 1997. But what it clearly struggled to do was reverse that in a fundamental way by producing a set of policies that really could reduce inequality, at least as measured by the Gini coefficient. A further consideration is the gap between the richer and the poorer areas. There was an impressive attempt to try and weight public expenditure towards those institutions like schools and hospitals in the most deprived parts of the country. My reading of the evidence, though, is that the gap between richer and poorer areas really began to accelerate in the late 1980 s and changed relatively little under New Labour ${ }^{9}$. So the record was mixed, with some novel initiatives, some real successes, and some areas where much more could have been done.

In the final section I will discuss key the-lessons; by reflecting on three key policy challenges which_, for me, emerge from the New Labour period corroborated by social policy experts like John Hills, Kitty Stewart and Geoff Mulgan. One is about area-based deprivation; the second is about

\footnotetext{
7 J. Hills \& K. Stewart, Towards a More Equal Society, Bristol: Policy Press, 2009 8 J. Hills \& K. Stewart, Towards a More Equal Society, Bristol: Policy Press, 2009 ${ }^{9}$ G. Mulgan, 'Going Against the Grain: Social Policy Since 1997', in W. Paxton \& N. Pearce, Social Justice: Towards a more Equal Society, London: Politico's, 2005.
} 
social mobility; and the third is about particular kinds of inequality which affect groups in the population that suffer acute multiple deprivation.

In relation to area-based deprivation, I think one can say that New Labour initiatives did go a long way to improving the physical fabric of the most run-down neighbourhoods, and strategies like New Deal for Communities [from 1998] did improve the physical infrastructure of the poorest parts of the country. What they were less successful in doing, though, was enhancing the human and social capital of the individuals and families that were living in those areas. ${ }^{12}$ I was very struck that by 2007 - so before the financial crisis - only $55 \%$ of adults in the ten most deprived wards in the country were actually in work. The strategy of trying to raise the employment rate, or trying to reduce worklessness in the poorest areas, had a very limited impact. I would argue that some of Labour's regeneration initiatives did not pay sufficient attention to the relationship between regeneration and wider issues relating to the structure of employment and wages $\frac{10}{}$. Moreover, while it's true that there was an attempt to have a regional economic policy, as mediated through the creation of RDA's, more could have been done to try to use regional economic policy strategies as a way of augmenting these regional regeneration initiatives, so that one was not just improving physical capital but was also thinking about how to improve the supply of relatively secure and well paid jobs within those areas.

The second policy challenge relates to social mobility, another contested concept in social policy. What seems to have occurred under New Labour was a flattening out in the decline of social mobility which had been on the rise from the mid to late 1970s. During the first decade of New Labour's education policy, the link between parental origins and educational performance in the secondary school system weakened $\stackrel{11}{ }$. Having said that, the UK at the end of the Labour period still had among the lowest rates of social mobility among the Organisation for Economic Co-operation and Development (OECD) countries. On access to university, within the richest $20 \%$ of the population, $77 \%$ of that population will go on to university - this is 18 and 19 year olds -compared to $46 \%$ within

${ }^{10}$ G. Mulgan, 'Going Against the Grain: Social Policy Since 1997', in W. Paxton \& N. Pearce, Social Justice: Towards a more Equal Society, London: Politico's, 2005.

${ }^{11}$ G. Mulgan, 'Going Against the Grain: Social Policy Since 1997', in W. Paxton \& N. Pearce, Social Justice: Towards a more Equal Society, London: Politico's, 2005 
the lowest $20 \%$ of the population, measured in terms of income per household $\frac{12}{}$. There is a significant class difference in relation to higher education access which has a bearing on structures of opportunity and social mobility in Britain.

The final policy challenge pertains to policies which try to reduce the effects of certain kinds of group-based disadvantage and the multiple penalties which particular kinds of groups face within the population. ${ }^{13}$ Just to give a couple of examples, women in low skilled, low income jobs have done much worse under New Labour than women at the higher end of the labour market. There is something structural about the position which women in low skilled, low wage parts of the economy face which clearly needs more attention. Part of this would be about trying to erode the gender pay gap in unskilled, casualised parts of the labour market. In relation to education, there are certain groups of people who come from particular ethnic minority backgrounds who do much worse at school. It remains the case that boys from Pakistani and Caribbean heritage households do far less well in the education system. Interestingly, a debate started to emerge at the end of the New Labour years about the performance of boys from white working class households: another facet of groupbased disadvantage. It is striking that disabled people also did quite badly during the New Labour period. If you measure levels of employment and real wages for the disabled population in the UK, they suffered a decline in their relative position in the period between 1997 and $2010^{\underline{13}}$.

To conclude, what New Labour lacked was a set of segmented strategies that were targeted at alleviating material and cultural deprivations experienced by specific groups in the population $\frac{14}{}$. By the end of the New Labour era it was recognised that what happens in the first three to four years of your life makes a fundamental difference to your life chances $\frac{15}{}$. A future Labour government has to think much more ambitiously about the kinds of policies it would introduce to tackle very early forms of life-course disadvantage. One of the arguments that Labour is going to have to engage in is a debate about intergenerational justice and about its willingness, not just to redistribute income from the rich to the poor, but also its willingness to redistribute income and resources from older groups in

12 J. Hills \& K. Stewart, Towards a More Equal Society, Bristol: Policy Press, 2009

13 J. Hills \& K. Stewart, Towards a More Equal Society, Bristol: Policy Press, 2009

${ }^{14}$ G. Mulgan, 'Going Against the Grain: Social Policy Since 1997', in W. Paxton \& N. Pearce, Social Justice: Towards a more Equal Society, London: Politico's, 2005.

$15 \mathrm{~J}$. Hills, Inequality and the State, Oxford: OUP 
the population towards those in the pre-school years, devising new policies to offset early childhood disadvantage. Thank you.

\section{Dominic Wring}

I'm going to talk about the party, focussing in particular on the question of why there was so much quiessence in a party, when historically Labour in office had experienced all manner of public and private debates. especially damaging public one. However, the period after 1997 was markedly different and, in fact, during the first term [1997-2001] there was only one conference defeat on pensions policy, and that was following the intervention of legendary party figure, Baroness Castle. To explore this issue I want to look at the changing structures and the changing nature of party organisation, concentrating on the period prior to Labour winning power in 1997.

Looking back to history, the electoral catastrophe of 1931 led to a reassertion of the extraparliamentary party's influence over decision making procedures. ${ }^{14}$ Subsequent leaders, especially Harold Wilson, were in the position of being conciliators and brokering between different factions within the party as well as the affiliated unions. It's quite noticeable how party debates were conceived in these terms up to the fallout from the 1979 election defeat and then the electoral catastrophe which was 1983. At that point there was a reassertion of parliamentary leadership control, especially under Neil Kinnock, although this is sometimes ignored in the New Labour literature. The crucial party changes came via Kinnock's Policy Review in the late 1980s, and this had three central elements.

First and foremost is what Lewis Minkin has written in his useful studies of Labour Party culture and its relations with trades unions in the 1970s and beyond. In the second volume he details the unprecedented ermergence of the Executive Leader's Office, as he calls it. ${ }^{15}$ This was constituted by a constellation of different actors in the mid-1980s: the campaign management team; the Shadow Communications Agency; various officials and specialist consultants; internal/external appointees what Eric Shaw calls a 'strategic community'. ${ }^{16}$ And it's noteworthy that a lot of the people who took office under Blair emerged at this point as crucial decision makers: Peter Mandelson, Philip Gould, Alastair Campbell, Tom Sawyer, Patricia Hewitt and Charles Clark. The same cluster of people 
eventually moved into government having served an apprenticeship under Kinnock. They were joined by the likes of Sally Morgan and figures who supplied a large number of Special Advisers. I think it is very significant and useful that there are so many Special Advisers here today to actually give us an inside view because it's a demonstration of how Labour politics has changed. If you want to know how decisions were taken, we are getting an insider account from, from, from people who were privy to this and this probably wouldn't have been true of previous generations. A further sociological aspect was the significance of the connections with think tanks that came to prominence under the new right in the 1970s and 1980s. You see similar think tanks - Demos, IPPR [Institute for Public Policy Research] and so on - working closely with the Labour government. It is telling that in the 2010 leadership election, four of the five candidates had served as Special Advisers in the early New Labour years.

The second element is the significance of the opinion-forming media in the mid-1980s. I am talking here about titles like Tribune which was significant with aligning itself with Kinnock and the so-called realignment strategy. Then, there were newspapers such as the Mirror, Guardian,

Independent which were popular amongst party members who were gaining entitlements to vote in plebiscitary ballots over Clause 4 and subsequently the road to the 1997 manifesto and one member, one vote which was brought in in 1993 . Here you see the origins of the importance and centrality of 'spin' in terms of negotiating with various journalists, which saw the transition from the 'Tory press' to the 'Tony press'. The significance of this characterisation by Peter Hitchens is that there was less support for the Labour Party and more for the character and leadership of Blair himself.

The third element is the significance of opinion research analysis and the reliance on focus groups and qualitative research. The initial wave from the mid-1980s involved researchers like Roddy Glen and Paul Southgate who worked on attracting the so-called aspirational electorate, the haves rather than just the have-nots, as the discourse went at the time. Noticeably, in a report in 1986 in Society and Self, which Philip Gould was pivotal to - I think it was his first major brief for the party there's a recognition that some of the public are less than favourable to the deserving and the undeserving poor, and this sort of discourse began to permeate party debates. We can subsequently see this in the way the Labour Party approached social justice when it was elected in 1997. One of the 
big debates at the beginning was about reducing single parent benefits. The money saved was relatively small, but it is suggested in many accounts of this period that it was done to appease the Sun and other newspapers that had obviously located their support for Blair in the 1997 election.

Having looked at those elements, they can tell us something about the erosion of traditional party representative democracy as a significant factor in Labour politics. This trend was symbolically underlined by Blair's decision in 2001 to create the position of Party Chair, appointing Charles Clark to the position, which indicates how the National Executive and the Party Conference had been somewhat downgraded and sidelined. This followed a significant challenging of the union link, as the debate was phrased in the aftermath of the election disasters of 1983 and 1992.The spin put on 1992 in particular was that the union link was to blame, when I think there is a lot of evidence to suggest it was a minor factor. At the time the debate was between the modernisers and the so-called traditionalists, and the union link was identified as a problem, when in truth there isn't a 'link' in that sense at all. The unions are actually affiliated members, a constituent part of the party. But the way it was framed at the time was to suggest they were a special interest group.

To conclude, I don't hold to this view that there is an 'old' and 'new' Labour Party: I think it is problematic in many different ways. Eloquently, Eric Shaw wrote about this pretty much as soon as the term began to gain common usage in the mid-1990s, criticising the tendency to write off everything that has gone before as 'old' when in fact it incorporates a myriad of different facets of the party and its political traditions. However, this terminology gained wide currency and in 2002 PR Week, the trade journal, awarded New Labour the award for public relations campaign of all time. It was a recognition of the significance of the changes made since the mid-1990s, whereas I would say crucial changes came before this period in terms of the party machinery. On the flip side, the use of 'new' is always canny in marketing terms and is a very useful device in terms of spinning the debate. It might have been more accurate to use the label 'new right Labour', in terms of the party's accommodation of the Thatcher economic reforms, as discussed before. Ultimately, therefore, Blair was a product of the New Labour project, rather than its creator. Thanks. 


\section{Foreign policy}

\section{Roger Liddle}

My talk will be in four parts: what was New Labour trying to achieve on Europe; how did it try to do it; what's the overall balance sheet of success and failure; and what lessons are to be learned? By New Labour I am talking about the trio of Gordon Brown, Tony Blair and Peter Mandelson, essentially

What was New Labour trying to achieve? That core New Labour trio all believed in the 'missed opportunity' interpretation of Britain's approach to Europe in the post-war era, put about in Hugo Young's great book, which was published around the time we took office. ${ }^{17}$ They wanted to end the perception of semi-detachment about Britain's relations with Europe and Blair said before the 1997 election that he would never see Britain isolated in the EU. This was in part a tactical, political position because it highlighted the weakness of John Major amidst the divisions in the Conservative Party at the time. It was also a strikingly sharp alternative to that of the ideological Thatcherites, who would turn their back on Europe.

So, it was part tactical but it also was, I think pro-Europeanism, a profound gut instinct of New Labour. This wasn't based on any great knowledge of the EU. Peter Mandelson was the one who engaged most in going onto conferences talking about Europe, but I don't think any of them had that much detailed knowledge of it. It was an instinct and it was not so much about Europe as the fact that Europe had been a definitional issue in the Labour Party's own history and development. They saw being pro-European as an absolutely essential part of a revisionist left position, and why was that? Tony Benn had argued, in the party arguments of the 1970s and 1980s for an Alternative Economic Strategy, one of the key points being that it was incompatible with our membership of the EU and the Treaty of Rome. Being pro-European for New Labour was basically recognising that we lived in a global market economy in which we couldn't choose a centrally-planned nation-state road to socialism.

Furthermore, being pro-European was - how should I put this? - positioning Labour as part of the West. Amongst the New Labour pro-Europeans there was absolutely no doubt that if you were pro-Europe, you were pro-America, and you were part of the West. Accompanying it was a set of 
positions on nuclear disarmament, which of course had been a crucial divisive issue in the Labour party of the 1970 s and the 1980s. It was also the case that Europe had played a key role in the Kinnock modernisation of the party, which Dominic referred to [above]. It was the first move away from the 1983 manifesto that Neil Kinnock made within a month of becoming leader - he went to address the EPLP [European Parliamentary Labour Party] in Strasbourg and he said, 'look, we've been members of the common market now for many years by the time of the next election; we can't continue going arguing for a position of coming out; what we've got to say is what kind of socialist Europe we want, and only then would we think about coming out'. From that move, the party became much more pro-European over the 1980s and this was consolidated in Jacques Delors's famous speech to the TUC in 1988 followed a few weeks later by Margaret Thatcher's response at Bruges.

Both Brown and Blair supported this commitment to Europe in general terms, but it was also helpful to them in their own roles as modernisers within the Labour Shadow Cabinet. Gordon was very committed to British membership of the Exchange Rate Mechanism because it was a guarantee that Labour could demonstrate that it was going to be a disciplined party that was going to be economically competent and would therefore command the confidence of the British people. For Blair the Social Chapter [on the basic employment rights of individuals] played into his role as employment spokesman as a way of shifting the Labour Party away from a commitment to reverse Thatcherite industrial relations reforms. By embracing the Social Chapter, Tony was also able to ditch things like the closed shop.

So that explains New Labour's European thinking. How did they intend to do this in government? My view in the 1990s was that Brown was much more committed to Britain joining the single currency than Blair. Gordon was of the view that if the single currency happened his instinct was that Britain should be part of it. Now, this had to be qualified as, of course, there was no certainty that it was going to happen and, indeed, for most of the 1990s a lot of informed opinion in Britain took the view, 'oh it will never happen', a repeat of Rab Butler's famous dismissal of the Messina talks in 1955 as 'archaeological excavations in an old Sicilian town'. The constant tendency of the British opinion-forming class to dismiss European integration as an unrealistic thing that will never happen was certainly present in the 1990s on the single currency. Brown's view, I think, was that, if it 
did happen, then we had to seriously think about being part of it. He feared becoming another Labour Chancellor who had been responsible for the devaluation of the Pound and he wanted the single currency to permanent locking exchange rates.

For Blair, it was always more conditional. He initiated the commitment to a referendum on the single currency when he had become leader. He was always convinced he could win this referendum, but, in his mindset, election victory was what had to come first. The thing that always struck me about Tony whenever I talked to him prior to 1997, including two days before the election was his extreme nervousness about the result. He didn't think, despite polls showing Labour $20 \%$ ahead, that Labour was going to win in 1997. I remember a few days before the poll him saying to me 'oh God, I think we'll be lucky if we have a majority of 40'. There was a nervousness that Labour would have a small majority, dependent on a left group in the parliamentary party that could cause as much havoc for the Labour government as a minority of Tory MPs caused for the Conservatives under Major. That was why he was so committed to courting the Murdoch press that nervousness was why he was so committed to courting - the Murdoch press. Blair's attitude to Murdoch was that he could persuade Murdoch to come round to the single currency.

Crucially, for Blair, the Euro played an important role in his vision of a 'big tent' politics. He basically wanted to create a big tent which embraced Labour, the Liberal Democrats, business and pro-European Conservatives. That was part of his political vision, and the referendum on the Euro was, for him, the way of bringing that political coalition together and making it last in government. The problem was, New Labour didn't work out a strategy for putting these aspirations into practice. Very shortly after we came into power, in the first half of 1998, the British had the EU presidency and we had really very little to offer. So, there was an attempt to build a strategy of engagement during 1998. Blair thought the way to win the public over to Europe was to demonstrate leadership. If you could demonstrate leadership and show that Britain was setting the agenda then the British people would rally to the European cause because they would see it as their project, not the project of the people on the other side of the Channel.

Brown had a more sophisticated view of what needed to be done in order to bring the British people round to Europe. His view was that the British people would never reconcile themselves to 
Europe until they had a much clearer sense of identity as Britons. However, the discussions about this were all rather inconclusive. The other thing that 'later' Gordon came to believe was that if you were going to persuade people of Europe, it had to be in the context of globalisation and therefore you had to think of Europe as a way of enhancing Britain's abilities to manage and to get advantage from the new realities of globalisation. So, these themes about Britishness and globalisation were very much Gordon's themes on the Europe front. Tony, I think, thought that the, the real way to deal with it was by leadership.

What's the balance sheet on this? A lot of academics have come to the view, which I basically agree with, that Labour had considerable success in Brussels and completely failed in Britain. Considerable success in Brussels in that a lot of the European agenda after 1997 had a very strong British imprint on it; there was the economic reform agenda; enlargement; a much more activist role for Britain in the EU's Justice and Home Affairs agenda and a strong impact on the climate change proposals. But in terms of public opinion very little progress was made.

On the negative side, it was too much of a business agenda and not enough of a social agenda. I partly buy into that, but I think that given that Blair's priority was to try and build this coalition that would take us into the Euro, it was inevitable that it would be a business-oriented agenda because his view was that the support of business would be crucial to winning a referendum vote on membership. The other criticism is of Blair's transatlantic 'bridge'. I remember Gerhard Schröder [German Chancellor] saying to him 'the trouble, Tony, is that it is a bridge in which in which there isn't much two way traffic', the classic example being Iraq. The interesting thing about Iraq, though, was that Blair's influence in Europe survived the disaster and he worked extremely hard to rebuild his European position. If you look at the period from 2005 to 2007, there was an Indian summer in the Blair premiership, in which he played a very big role in Europe. In 2005 there was the budget deal, climate change, Africa, and agreeing the outlines of what became the Lisbon treaty: all of these things were achievements in that period.

Blair also survived in terms of British influence by not being in the Euro. Why did Euro membership never happen? I think it might have happened in the first term if we'd had a referendum within a couple of years of the 1997 election; Brown could have been brought on side at that stage. 
But, for Brown, the calculus changed on the Euro during the second half of the first term. First of all, the economic framework that he'd established, based on independence for the Bank of England, actually worked; why change it when it was working? Secondly, politically he began to think about his position as heir apparent to the premiership, and the way that he chose to consolidate that position was that he pitched left on public services to make people think he was more to the left on public services than the public service reform agenda Blair was pursuing. The third thing is that he felt the balance of economic risk in terms of joining the Euro changed. By 2003, I think that he felt that if we were to join the Euro it would mean lower interest rates, and that would mean that taxes would have to go up to compensate for the looser monetary policy. That was at a time when he was running very big increases in public spending and he felt that this would get in the way of the strategy of the government, and for all this mix of reasons his calculus changed.

By contrast, Blair became more committed to the Euro as the second term went on. He was furious that Gordon wouldn't bow to his view on the assessment about the Euro when it was carried out in 2003 but he had very little alternative because decision on the Euro assessment was taken at the same time as parliament was voting on whether to go to war in Iraq. He had very, very few political options. However, he still hoped that after victory in Iraq he would enjoy what was in Downing Street referred to at the time as a 'Baghdad bounce' which would enable him to get the campaign for a Euro referendum going in 2003/4. It was the sad death of Dr David Kelly that finished all of that off. It wasn't the Iraq war, it was the death of Dr David Kelly in the summer of 2003 that forced Blair to abandon any hopes of joining the Euro during his premiership.

What are the lessons learned? The criticism I would make of New Labour is that its European policy became merely an add-on to a strategy of social democratic renewal. It wasn't an existential choice as far as your political project was concerned. It became a mantra that Britain should be active and committed members of the EU but it wasn't central to what we had or needed to achieve. The second point is that the prospects for a nation-state, Keynesian solution to Britain's problems are rather restricted and, therefore, we have to think in terms of how we win support for a European-wide growth agenda. Thirdly, there are flaws in our model of capitalism and if we want a more responsible model of capitalism, we should be looking at the European models with more attention and thinking 
about how European regulation can buttress the kind of capitalism that we want to see. Finally, I think that the 2000s saw a flowering of British influence in the world under Blair - some positive, some negative, but on the whole a very internationalist, engaged agenda which I think, in the circumstances post-financial crisis, we are no longer able to pursue. Therefore, if we have ambitions for leadership in the world in the new circumstances we have to put much more emphasis on European cooperation, particularly given that America is turning more towards the Pacific. Thank you.

\section{Oliver Daddow}

The thrust of my remarks is that there appear to be two New Labours in evidence from the period 1997-2010. One lasted from around about 1997 to 2010 and was reasserted to a degree in post-Blair New Labour, so the Gordon Brown/David Miliband years, centring on multilateralism and a Europeanist agenda. The other New Labour is that second term into third term Tony Blair; 2001 through Iraq and Afghanistan. This is the better remembered period which will always be associated with New Labour's foreign policy adventurism. That's an era that drew very much more on the Atlanticist tradition in British foreign policy, so something much more familiar to the Conservative party, not least Winston Churchill and beyond. Depending on who you are and what you want to study, you will probably draw upon one or both of those different New Labours.

My first big point in support of this argument is that New Labour didn't have a well worked out foreign, defence and security plan when it came to office. It obviously admitted that the use of force might well be an option, but what New Labour did in the run-up to 1997 was not throw out any hostages to fortune because it didn't want to open and flanks for criticism. We know that the Old Labour Party, if we want to use that terminology, was very suspect on defence - unilateral disarmament and so on - and one of the successes of New Labour was to construct itself as more trustworthy on defence. However, that hadn't by 1997 translated into a proactive set of policy proposals, partly for tactical reasons, but also because New Labour was in a constant state of development. New Labour people knew that they didn’t want to be Old Labour, but a positive vision on the use of force was lacking, even into the 1997 election manifesto. 
In government, naturally, things started to alter. In July 1998 the Strategic Defence Review (SDR) was published, so you started to get much more of a sense of where New Labour was going to go. The key portions of the SDR were its expeditionary focus and the transition to post-Cold War platforms for doing that - going to a crisis rather than waiting for the crisis to come to Britain. Even documents like that can be superseded by earth-shattering events like 9/11 and that's how it proved. Within three years, the SDR had to be updated with a 'new chapter'. The focus there was on asymmetric conflicts, centring on terrorism, accompanied by a reassertion of the Atlanticist tradition in British foreign policy.

My second main point is that to understand Blair it is too easy to look only at Iraq. We sometimes make the mistake of ignoring what happened in the first term and in that regard Kosovo in 1999 is probably a more interesting prism through which we see that original New Labour vision just starting to develop and be played out. Blair at that point was interested in foreign policy only insofar as he understood the link that it created between globalisation on the one hand and national economic policy-making on the other. During Kosovo, however, he was compelled to think more critically about globalisation and national security and he did this through his April 1999 Doctrine of International Community speech, which he stumbled on partly through a hasty speech writing process. ${ }^{18}$ This wasn't Blair delivering a vision he already possessed; making policy on the hoof is a slightly unfair accusation, but he was certainly thinking creatively as events hit him.

My third point is that it is not particularly easy to draw a straight line from early Blair to later Blair to say 'here is, is an zealous supporter of liberal democracy promotion waiting to get out'. Even after 2001 it wasn't inevitable and there were choices to be made. George Bush did give Tony Blair an 'out' by suggesting 'look, we can do Iraq without British troops, without British engagement; we don't need you. If it is going to be problematic, don't worry'. But Blair was committed after 9/11 to standing shoulder to shoulder with the US.

This analysis of different Blairs and different New Labours reveals a few questions about the New Labour years in foreign policy. Firstly, how are foreign policy decisions best made, particularly in a crisis? Restrictive decision-making processes can lead to groupthink, where contrary evidence gets ignored or filtered out. This is a view put most forcefully by former Blair's ministers such as 
Claire Short [Secretary of State for International Development May 1997 to May 2003] and Robin Cook [Foreign Secretary May 1997 to June 2001]. However, other Blair advisers, such as Alastair Campbell [Downing Street Press Secretary May 1997 to August 2003] argue that, at the end of the day, it is better to have a Prime Minister who makes decisions, or one that doesn't make decisions, or does so laboriously that they aren't timely or effective.

Second, coalitions of the willing were not unknown in post-Cold War intervention practices and there was precedent for going in without the UN, as we saw in Kosovo. So, do all interventions need UN backing? They ideally need legality but if the UN isn't willing to sanction or can't agree, is it ethical or not to act? Thirdly, it appears Blair seriously believed he could act as a moderating influence on Bush. However, I wonder if the Blair foreign policy team at this time really understood how foreign and defence policy was made under the Bush administration. Blair talked about a 'special relationship' but did Downing Street understand the dynamics of that? I'm not totally sure.

What lessons can we learn from the New Labour years in foreign policy? Firstly, that the New Labour agenda of early Blair the later, Gordon Brown/David Miliband nexus - has in many ways come to be accepted and practiced by the coalition government, except it is now called 'liberal Conservatism'. David Cameron and William Hague supported the Afghanistan and Iraq operations and they have continued to work ethics and values into British foreign policy. But what they have done is give it a much more capital ' $R$ ' Realist slant, which is much more focused on national interest as they would see it. The second lesson is that Ed Miliband might usefully take the Labour Party back towards its internationalist roots, drawing on a tradition effectively practised by early Blair and New Labour under Gordon Brown. However, he would need a resonant narrative to achieve this, and we've gone through ethical dimensions to foreign policy, we have gone through liberal Conservatism. There is an idea that you could develop a policy idea themed around ethical realism, which is a bit like liberal Conservatism with different words, flagging up development aid and poverty reductions of drivers of more international security. That could be a viable option.

Finally, the main dilemma facing the coalition and which Ed Miliband will almost certainly face as well, is the nature and scale of the global financial crisis which is shrinking the kinds of resources available in Britain to fund a globally proactive foreign and defence policy. The use of force 
as a point of contestation in British politics is very rarely going to win or lose an election, so it's not a salient issue for voters. Yet, even barring some sort of existential threat to British territory itself, the British public remain wary of the Iraq legacy, so the blunt use of force is unlikely to be a first choice for any Ed Miliband government. There is now a higher threshold on the deployment of troops, plus it is economically prudent and ideologically pragmatic as well. The memory of Iraq will loom large in any discussion of Labour's foreign policy, but Ed Miliband might be advised to concentrate on developing the thinking of that first term Blair. Thank you.

\section{Mark Phythian}

The first point I'd like to make about New Labour and the intelligence services is that the New Labour effect in this area can be traced back to the important role that individuals who would feature in the Blair and Brown governments played in the debates about the introduction of formal intelligence oversight in the UK in the 1990s. In particular, Robin Cook as early as 1979 had introduced a bill to put the agencies on a statutory footing, a move which Margaret Thatcher was implacably opposed to. The creation of formal intelligence oversight in the UK came via the Intelligence Services Act in 1994 which created a Parliamentary Intelligence and Security Committee (ISC), appointed by the government of the day rather than by Parliament. But this was conceded from a position of relative weakness. The government and agencies had conceded this in recognition of some kind of democratic deficit in this area, so it was developed from a position of weakness. Even though it was an accomplishment of the John Major government, therefore, I doubt it would have occurred at this time and in this form absent the pressure from key Labour figures. Beyond Robin Cook, Chris Mullen's role in the Home Affairs Committee at the time was also important.

My second point is that this reflects a history of tension between the security and intelligence services and the Labour Party, marked by famous instances like the 1924 Zinoviev letter; suspicions of a 'Wilson plot' fuelled by Peter Wright's Spycatcher memoir; ${ }^{19}$ former M15 officer Cathy Massiter's mid-1980s revelation that future Labour government ministers Harriet Harman and Patricia Hewitt had been placed under surveillance by MI5 as a consequence of working for the National Council for Civil Liberties which, at the time, MI5 classed as a subversive organisation; the memoirs 
of Oleg Gordievsky and the revelation, or the claim, that Michael Foot was an agent of influence for the Soviet Union. All of these episodes meant that the Labour party saw itself less of a partner in security and intelligence and more of a target of security and intelligence.

Symbolically, in light of this, one of Robin Cook's first actions as Foreign Secretary early in 1998 was to commission an investigation into the Zinoviev affair, based on the MI6 archive, aiming to put to rest once and for all the swirling allegations and suspicion it invited. But that was just one current in New Labour; intelligence was, in effect, for New Labour an extension of defence. As Oliver suggested earlier [see above], intelligence was regarded as an area of inherent weakness by New Labour, about which people like Blair and Philip Gould worried ceaselessly. It was an area, like defence, where Labour had few friends in the profession and little expertise in parliament. And, to the extent that New Labour defined itself by the extent to which it had moved on from the 1983 general election manifesto, this created a tension with regards to intelligence because the manifesto committed a future Labour government to introduce legislation to provide oversight by a select committee in the House of Commons. This history between Labour and the intelligence services also helps explain why, after the 1997 general election victory, Blair retained Tom King, former Conservative Defence and Northern Ireland Secretary, as the chair of the ISC, rather than replace him with a Labour MP. It would only be with King's retirement from the House of Commons in 2001 general that a Labour MP would take over as chair and this was the point at which the committee's fortunes dipped.

So, on this reading then, Labour's commitment to oversight was in many significant ways very Old Labour. It wasn't part of the New Labour self-image; it was more what New Labour was seeking to move on from and, as such, wasn't a New Labour priority. During Blair's first term, the Labour government's approach to intelligence can best be described as one of benign neglect. This was the most positive relationship that the intelligence agencies could expect, because this was a decade when people were speculating about the 'peace dividend' being extended to security and intelligence. With the demise of the Soviet threat, MI5 and MI6 were engaged in a very public turf war about who should have primacy over the counter terrorist operations in Northern Ireland. When the Good Friday agreement was signed, MI5 suddenly realised that it had unique expertise in serious 
organised crime and it was the natural agency to lead on that. Benign neglect and there not actually being budget cuts was actually felt to be a very positive gesture towards the agencies on the part of the Labour government.

Unexpected events meant that the intelligence and security context was twice transformed twice during the New Labour era. Both transformations highlighted the erosion of the traditional distinction between domestic and foreign intelligence. The first transformation, a consequence of the 9/11 attacks and the launching of the war on terror, impacted primarily on foreign intelligence collection, on GCHQ and MI6, and on foreign intelligence partnerships. The second transformation came in the wake of the 7 July 2005 [7/7] London bombings, and this impacted on domestic security. The Iraq war connects these transformations as a consequence of the first and a driver of the second but on its own it was not a driver of any kind of revolution in intelligence affairs in the UK.

The combined impact of these two transformations was to increase the size, funding and scope of the security and intelligence sector in the UK, and this is a key New Labour legacy. At the time of the 9/11 attacks, MI5 employed around 1,800 people. Post-9/11, the agency expanded rapidly to meet the threat posed by domestic Islamist terrorism. By 2008, so just after Blair's departure, it employed just over 4,000 people, more than double its size at 9/11. While the founding threat that MI5 was designed to protect against - foreign subversion - remained, by the end of the Blair and Brown premierships, MI5 was essentially a counter-terrorist organisation. The proportion of resources allocated to counter-terrorism increased annually post-9/11. By 2003/4 it already devoted $66 \%$ of its resources to counter-terrorism, but $25 \%$ within that was spent on countering Irish terrorism. By 2005, counter Islamist terrorism alone accounted for $56 \%$ of MI5's operational efforts and by April 2008, MI5's counter terrorist-focus accounted for $91 \%$ of its budget.

At the same time, it was over the Iraq War and the London bombings that the ISC and existing oversight arrangements lost much of their credibility. In both cases the Committee was seen to have pulled back from investigating the nexus between the intelligence community and policymakers and it was subsequently seen that the intelligence making services would offer limited cooperation and had withheld information from the inquiries. Public confidence in intelligence oversight was so dented that, by 2007 , the Brown government felt obliged to go public and recognise 
some of the limitations of the ISC, the first time a government has ever done this, and to propose reforms. But by this time the limitations of the ISC were quite widely recognised; both the Conservative and Liberal Democrats in opposition were also in favour of moving towards a more formal select committee style of intelligence service oversight. Brown also tried to ensure that the Chilcot enquiry into the Iraq war was conducted behind closed doors, an effort which ultimately failed, he backed away from, but ultimately had to back down on this.

The impression we are left with is that the Brown Labour government had much to hide in security and intelligence. By the time of the 2010 general election the government was hardly seen as a champion of open government or civil liberties, without even going into the post-7/7 insistence on the need for 90 days pre-charge detention of terrorist suspects. There had been a series of war on terror-related questions about, for example, government involvement or acquiescence in US extraordinary rendition, the possibility of MI5 acquiescence in torture of detainees in Pakistan, culminating in the rescue of documents showing that MI6 was complicit in the extraordinary rendition of Libyan dissident Abdulhakim Belhadj, the Gadaffi regime, generating a trail that led back to the responsible minister of the time, Foreign Secretary Jack Straw. Straw's response, when he was still talking about this, was that no Foreign Secretary can know all the details of what all intelligence services are doing at any one time. But Sir Richard Dearlove, head of MI6 at the time of the renditions, made it clear that, quote, 'it was a political decision. How very significantly disarming it would be for the government to cooperate with Libya on Islamist terrorism'.

What did New Labour achieve in this area? Well, initially, its aims were less to do with policy and more with the way in which the Labour Party was perceived by the intelligence and security services. The mutual suspicion that did much to characterise the historic relationship between Labour and intelligence was largely eliminated as a consequence of the New Labour approach to intelligence. Blair certainly succeeded in banishing the ghosts of Old Labour here: a relationship that began by being marked by suspicion and distance ended, paradoxically, with a new set of problems generated by the fact they were too close and unquestioning. The roles of Richard Dearlove and John Scarlett in the production of the September 2002 Downing Street dossier on the Iraq and its Weapons of Mass Destruction symbolises, is summed up by Alistair Darling's comment that John Scarlett was 
quite a 'good mate'. Added to this, by the end of New Labour era, the intelligence community in Britain was more professional, more representative of the population and more open than it had ever been before in its history, I think we are still too close to events to actually gain a perspective on what professionalisation means in this case, or when it took place. It's ongoing and, clearly post-Iraq, and the recommendations of the Butler Report - there was another spurt of professionalisation.

Iraq and its legacy must feature on the debit side of the balance sheet. The debate about reform of the intelligence oversight that's taken place post Iraq has been about restoring public trust in the agency, something which, which was severely undermined by the manner of the Iraq decision and also the role of intelligence in the creation of the Downing Street dossier.

The lesson for governments of whichever party in the UK or in Western democracies, is that intelligence should be treated in a more mature and open manner, consistent with the level of taxpayer investment it now requires. An advantage of this would be that more regular informed public discussion would help educate the public and parliament as to what can be expected of intelligence, and about the limits of intelligence. This, in turn, should be a vital dimension of debates on how much should be invested in intelligence, particularly important in an age of economic austerity. There is a sense in which policy on intelligence has been driven by a kind of technological determinism over the last 20 years, where technological fixes have been bought in regardless of the cost, and I think we are long overdue a debate about the wisdom of these and what advantages they deliver.

There is also a sense in which the expansion of intelligence and security at the domestic level has led to a creeping what you might call 'Singapore-isation' of British domestic politics, where it is held that it is through an understanding the limits of freedom that freedom is made possible. This also indicates that a more public debate is important. Given that we now have a national security strategy that brings together intelligence and defence, it really is a missed opportunity that the Labour Party isn't talking about intelligence alongside talking about defence and interventionism.

\section{Conclusions: lessons learnt}

These witness testimonies coalesce around several themes from the New Labour years which offer up lessons for a future Labour government but which are germane to the governance of Britain more 
generally. The key policy lessons relate to the economy and the country's role in the world, containing within them issues pertaining to political marketing and how to handle the machinery of government and build the requisite coalitions of support to deliver stated policy objectives. It should be noted that these conclusions predate the result of the Scottish referendum on independence from the UK, as well as the likely referendum on Britain's membership of the European Union, pencilled in for 2017. Both, clearly, will provide hugely altered circumstances for the future governance of Britain.

The first set of lessons relates to economic management. The advisers agreed that Labour's economic record was mixed, even prior to the 2008 global financial crisis which has tarnished that record with accusations of over-spend and under-saving when the economy was in a healthier condition. Dan Corry pointed out that Labour was trying to move the economy in a 'social democratic' direction - something he sees as distinct from simplistic charges of 'neoliberal' deregulation and low taxation. He reflects on overlooked 'micro' changes, for example to corporate governance and the labour market, as well as New Labour's mixed record on implementing publicprivate partnerships and regional aid. Like Corry, Geoffrey Norris flagged up New Labour's need not only to be competent economic managers but to be seen to be competent given the party's undistinguished past and associated lack of trust in Labour's record on the economy, dating back at least as far as the 1970s. The economic liberalisation agenda, Norris argued, went furthest and most successfully in energy supply but the government oversaw an 'atypically sharp' decline in manufacturing. The unexpected and unexpectedly severe global financial downturn necessitated new thinking on industrial policy, with the government desperately pulling any lever it thought might help the ailing economy.

Patrick Diamond's analysis of New Labour's thinking on social justice reflected the same concern with the adaptation of 'Old' Labour thought to the 'new' demands of limiting unemployment, income inequality and poverty, and the effective management of public services, in a globalising economy. Patchy achievements, he suggested, mean that future Labour governments need to have a clearer and more positive vision for the role of the state in the provision of public services and in promoting desirable collective objectives such as social mobility and equality of opportunity and life 
chance. Indeed, as Dominic Wring points out in his remarks, the conceptual distinction between Old Labour and New Labour might have been effective as a marketing tool, but it in fact masked from view to those making the New Labour Party the elements of prior thinking that could have been helpful in confronting the whole range of challenges the Blair-Brown faced in office. Elements of 'groupthink' clearly crept into New Labour's political strategy, and this was particularly damaging when splits between the Blair camp on the one hand and the Brown camp on the other stultified the potential for a powerful governing coalition to be put in place behind some of New Labour's more radical or contentious ideas to improve life in Britain for the worst off and most needy.

The New Labour insiders all agreed, therefore, that the Blair/Brown governments could have done much more to progressivise the economy along centre left lines when the scope for radical changes was at its greatest pre-financial crisis. For instance, tackling early forms of life-course disadvantage, being open about accepting a more positive role for the state in the delivery of public goods, and being braver at setting out a course and building the coalitions in and outside government to push through the necessary reforms - New Labour seemed to take several years to get into its stride as the party of government. Perhaps this was understandable, because there was limited to no experience at actually being in government on the part of the key New Labour people. Yet the feeling remains that these governments could have manipulated the machinery of government more effectively than they did. Furthermore, there was a sense of regret amongst the contributors that policies unfolded reactively as crises arose - too often especially in response to media headlines and agendas - rather than being devised, implemented and communicated in a thoroughgoing engagement with public and opinion forming actors in civil society. A future Labour government may well hark back to the Gordon Brown dictum that Labour is 'best when we are boldest' ${ }^{20}$. However, it is fair to suggest that the next government's economic inheritance will be intrinsically poorer than was New Labour's 1997 inheritance, so perhaps the time for boldness, for example on public spending, has been and gone. Economic governance in Britain increasingly has become a tale of managing extremely limited funds in the most effective and efficient way possible to achieve limited but quantifiable objectives. Britain may not be broke or in economic crisis by the time of a next Labour government but austerity measures will still be in place, necessitating a clear economic narrative 
about how growth will be achieved as well as a carefully planned set of strategies and subtle use of the machinery of the state to safeguard it.

The second set of lessons relates to foreign policy and Britain's role in the world, where the New Labour strategy - such as it was - was judged by all the speakers to have been mixed at best. In contrast to the amount of time spent planning economic policy centring on eye-catching initiatives such as independence for the Bank of England, New Labour did not enter government with a clear foreign policy agenda it then implemented. It lacked a grand vision, beyond some rather vague aspirations about giving the country strength and 'confidence' in its dealings with Europe and the wider world. Blair himself was not enthused by the idea of spending time probing the question of 'Britishness' and he left this dimension to Gordon Brown. The Chancellor, however, 'was never satisfactorily able to translate what he identified as distinctive British values into a set of concrete guiding principles about Britain's role in the world'. ${ }^{21}$ As Mark Phythian adds, New Labour's dedication to improving relations with the intelligence and security machinery of state paid some dividends internally to the party, but ultimately could not assuage the damage and loss of trust resulting from the Iraq and Afghanistan invasions, the ramifications of which are unfolding to this day and are becoming wrapped up with the rise of terrorist bodies such as Islamic State. Critically, the speakers found, New Labour people had not thought terribly hard about how to fashion a cohesive British identity which could form the basis for a foreign policy expressing and supporting vital British interests.

Reactiveness in foreign policy is a given, particularly for a medium-sized power such as Britain which exists in an anarchic international system and in an international community which is divided into so many strands of opinion on how to represent and respond to security challenges - look at the problems of achieving consensus within the EU, NATO and the UN on how to respond to the Russia-Ukraine imbroglio which is ongoing at the time of writing. So an element of reactiveness is, necessarily, woven into the fabric of foreign policy decision-making, particularly when the country in question proudly proclaims to want and need to be all over the globe actively supporting and promoting its national interest. All the speakers argued, however, that this might have been part of the problem in the period 1997-2010, such that the New Labour years were characterised by a potent mix 
of promise unfulfilled and, later, hubristic over-estimation of Britain's ability to assuage complex security problems through the use of military force. Lack of forward planning and a clearly defined exit strategy characterised the conduct of the Afghanistan and Iraq invasions, and this was in stark contrast to the relatively more successful - and limited - British involvement in Operation Allied Force in Kosovo in 1999. In hindsight, as Oliver Daddow contended, Kosovo appears to have been one of the more successful Blair foreign policy adventures and proved to be a defining moment in Blair's search for a 'big' foreign policy idea: liberal intervention associated with the 'doctrine of international community'. ${ }^{22}$ That this idea became corrupted in the aftermath of $9 / 11$ shows how even the most high-minded foreign policy ideas can be subverted by poor policy planning and/or shorttermism resulting from knee-jerk, particularly in times of perceived global 'crisis' when the kaleidoscope of international relations is in a state of flux. The Coalition government has set a higher threshold on the use of military force to achieve foreign policy objectives (for instance being guided by the parliamentary vote against the use of force in Syria in August 2013). Time moves on, but by dint of association a future Labour government will be executing foreign policy in an era when the shadow of Blair's adventurism still looms large over the national debate over British foreign policy and the public appetite for military intervention remains low.

As Roger Liddle suggested, however, the Iraq-dominated assessment of New Labour's foreign policy record obscures the fact that Blair's biggest regrets is probably going to be that he never managed to fashion a deeper national consensus about Britain's role in the EU. In some ways this was the touchstone foreign policy issue Blair was interested in when he came to office. Yet it became a story of speeches made but not followed up on allied to - and in part a product of - a consistent refusal to tackle the Euroscepticism of the tabloid press, particularly centring on the views of Rupert Murdoch's newspapers and those on the Conservative right such as the Daily Mail and Daily Telegraph. Early refusal to join the Euro set the tone for a policy not driven by a principled form of pro-Europeaninsm but by the perceived need to quieten media dissent. Certainly New Labour failed to provide a consistent steer to UK public opinion on European affairs. As the New Labour years progressed it became evident that Europe had been subsumed into the behind-the-scenes 
wrangling between Blair in Downing Street and Brown at the Treasury, with the latter actively courting the Eurosceptic press in an attempt to gather support for his stint as prime minister.

The early decision against Euro membership was a particular barrier to the creation of a Europeanist foreign policy, and one that was hastily conceived on the back of bungled press briefing by the Brown camp. Later trumpeted as a major policy success when the Eurozone crisis erupted, at the time of making the decision in late 1997 things were not clear-cut. Single currency membership could, arguably, have done more to enhance New Labour's Europhile credentials than any set piece speech and helped New Labour accrue political capital where it mattered - in Paris, Bonn and the EU institutions. This decision ducked, there was still potential that got frittered away. New Labour spent its years engaging energetically with the EU on the diplomatic front - even showing considerable leadership on such matters as climate change and common defence - whilst flirting with the language of Euroscepticism to sell its policies domestically. The press in particular consistently clamoured for a 'say for the people' on the EU and the fruits of New Labour's policy can now be seen in the likely holding of a referendum on UK membership of the EU in 2017.

In foreign policy, as domestic policy, therefore, this collection of testimonies advances our understanding of UK governance by flagging up the need for governments to devise an overarching narrative or 'vision' which goes beyond daily 'spin', combined with hard policies designed to implement that vision. Politicians spend a lot of time talking about leadership, but it seems they could spend more time exerting leadership to build the support necessary to driving through their objectives. Actions very often do speak louder than words.

\section{References}

Blair, T. 'Doctrine of the International Community' speech, Chicago, 24 April (1999). Available at http://www.britishpoliticalspeech.org/speech-archive.htm?speech=279 [accessed 15 September 2014]. 
Brown, Gordon. Speech to the Labour Party conference, Bournemouth, 29 September 2003. Available at http://www.theguardian.com/politics/2003/sep/29/labourconference.labour1 [accessed 15 September 2014].

Corry, Dan. 'Labour and the Economy, 1997-2010: More than a Faustian Pact'. In Reassessing New Labour: Market, State and Society under Blair and Brown, edited by Patrick Diamond and Michael Kenny, Political Quarterly, 81, issue supplement S1 (2011), pp.123-39

Corry, Dan, Valero, Anna and Van Reenen, John. 'UK Economic Performance since 1997: Growth, Productivity and Jobs', London: Centre for Economic Performance (London School of Economics and Political Science), November 2011.

Daddow, Oliver. “"Tony's War?” Blair, Kosovo and the Interventionist Impulse in British Foreign Policy', International Affairs 85, no.3 (2009): 547-60.

Hills, John. Inequality and the State. Oxford: Oxford University Press, 2010.

Hills, John et. al. Towards a More Equal Society. Bristol: Policy Press, 2005.

Liddle, R. The Europe Dilemma: Britain and the Drama of European Integration. London: I.B. Tauris, 2014 
Minkin, Lewis. The Contentious Alliance: Trade Unions and the Labour Party. Edinburgh: Edingurgh University Press, 1992.

Shaw, Eric. The Labour Party since 1979: Crisis and Transformation. London: Routledge, 1994.

Wright, Peter. Spycatcher: The Candid Autobiography of a Senior Intelligence Officer. London: Viking Press, 1987.

Young, Hugo, This Blessed Plot: Britain and Europe from Churchill to Blair. London: Macmillan, 1998.

\section{CONTRIBUTOR BIOGRAPHIES}

\section{Dan Corry}

Dan has been Chief Executive of New Philanthropy Capital since October 2011. He was Head of the Number 10 Policy Unit and Senior Adviser to the Prime Minister on the Economy from 2007 to 2010. He has been Chair of the Council of Economic Advisers in the Treasury and has worked as a special adviser to the Secretary of State in the Education Department as well as at Department of Trade and Industry and the Department for Communities and Local Government. Most recently he was a Director in the Economics segment of FTI Consulting. In addition to working at senior levels of government, Dan ran the New Local Government Network think tank between 2002 and 2005 and was Senior Economist at the Institute for Public Policy Research in the 1990s. More recently in his role 
at FTI Consulting, Dan's work included an analysis of the cost effectiveness of the Family Rights Group and of Tomorrow's People.

Dan is a Visiting Fellow at Southampton University, a trustee of the Spitalfields Centre Charity Trust, a member of the Greater Manchester Economic Advisory Panel, a member of the Research Committee of the ESRC and a member of the Advisory Board of CentreForum, a liberal think tank.

\section{Oliver Daddow}

Oliver Daddow is Reader in International Politics at the University of Leicester. His research interests are in interpretivist international relations, British foreign policy and Euroscepticism. He is the author of New Labour and the European Union: Blair and Brown's Logic of History (Manchester University Press, 2011) and Britain and Europe since 1945: Historiographical Perspectives on Integration (Manchester University Press, 2004). He edited Harold Wilson and European Integration: Britain's Second Application to Join the EEC (Frank Cass, 2003). With Jamie Gaskarth he co-edited British Foreign Policy: The New Labour Years (Palgrave Macmillan, 2011), and with Mark Bevir and Ian Hall he has coedited Interpreting Global Security (Routledge, 2014). He has written book chapters and peer reviewed journal articles across his research interests, including in International Affairs,

Political Quarterly, British Journal of Politics and International Relations, Cambridge Review of International Affairs and Review of International Studies.

\section{Patrick Diamond}

Patrick Diamond is Gwilym Gibbon Fellow at Nuffield College, Oxford, a Visiting Fellow in the Department of Politics at the University of Oxford, and Lecturer in Public Policy, Queen Mary, University of London. Patrick was also an elected member of Southwark Council. He 
is the former Head of Policy Planning in 10 Downing Street and Senior Policy Adviser to the Prime Minister. Patrick has spent ten years as a Special Adviser in various roles at the heart of British Government, including No.10 Downing Street, the Cabinet Office, the Northern Ireland Office, and the Equality and Human Rights Commission (EHRC) where he served as Group Director of Strategy. His recent publications include: Beyond New Labour (with Roger Liddle, 2009); Social Justice in the Global Age (with Olaf Cramme, 2009); and Global Europe, Social Europe (with Anthony Giddens, 2006).

\section{Roger Liddle}

Roger Liddle is Labour's front bench spokesperson on Europe in the House of Lords. He chairs Policy Network, the international progressive think tank, and is a Director of the University of Cumbria. For seven years from 1997 he was special adviser on European affairs to the British Prime Minister, Tony Blair. From 2004-2007 he served in the European Commission, first in the Cabinet of the EU Trade Commissioner and then as economic adviser to the European Commission President, Jose Manuel Barroso.

Roger has written extensively on European and British affairs, including The Blair Revolution (with Peter Mandelson, 1996), Global Europe, Social Europe (with Anthony Giddens and Patrick Diamond, 2006) and Beyond New Labour (with Patrick Diamond, 2009), as well as several other Fabian Society and Policy Network pamphlets. He also co-authored two papers for the President of the Commission's thinktank, the Bureau of European Policy Advisers, on "Europe's Social Reality" (February 2007) and the "Single Market: Yesterday and Tomorrow" (July 2006), and since then has contributed to various edited collections on the Single Market, the social challenges facing Europe, the case for a social investment strategy and Britain's European policy. 


\section{Geoffrey Norris}

Geoffrey Norris is an expert in energy and industrial policy and has been at the heart of business policy-making in the UK for the last decade. He was one of the key architects of Britain and Europe's current approach to energy policy and climate change. He worked for more than ten years as the principal business adviser in 10 Downing Street to Prime Minister Tony Blair and then Gordon Brown. Most recently he was a special adviser at the UK Department of Business in Whitehall.

\section{Mark Phythian (Professor of International Security, University of Leicester)}

Mark Phythian is Professor of Politics in the Department of Politics and International Relations at the University of Leicester. His research interests are in the areas of intelligence, national security and foreign policy. He is the author or editor/co-editor of a number of books - including The Politics of British Arms Sales Since 1964 (Manchester University Press, 2000), The Labour Party, War and International Relations 1945-2006 (Routledge 2007), Intelligence in an Insecure World (with Peter Gill, 2nd ed. Polity Press, 2012) and (as editor) Understanding the Intelligence Cycle (Routledge, 2013) - as well as numerous journal articles and book chapters.

\section{Dominic Wring}

Dominic Wring is Reader in Political Communication at Loughborough University. His publications include The Politics of Marketing the Labour Party and lead editor of Political Communication in Britain: the Leader Debates, Campaign and Media in the 2010 General Election. He was a founding and European Editor of the Journal of Political Marketing, helped create and convene the UK Political Studies Association's Media and Politics Group and has also chaired the International PSA's Political Communication Committee. He is 
particularly interested in the continuities as well as changes in party organisation and has written about the development of electioneering in Britain since the advent of mass democracy a century ago.

\section{NOTES}

${ }^{1}$ We are grateful to Laura McKenzie for transcribing the workshop text in full, and to the anonymous comments on the initial submission provided by the journal referees.

${ }^{2}$ For further development on the issues raised here see Corry, 'Labour and the Economy'

${ }^{3}$ Peter Mandelson was, briefly, Secretary of State at the DTI between July and December 1998.

${ }^{4}$ In England nine RDAs were created under New Labour. The Coalition government introduced legislation to scrap the RDAs in June 2010 and they were finally abolished in June 2012. The rejection by referendum in November 2004 of plans for a Regional Assembly in the North East scuppered New Labour's wider scheme to introduce Elected Regional Assemblies outside of London.

${ }^{5}$ Corry, Valero and Van Reenen, 'UK Economic Performance'.

${ }^{6}$ The Gini coefficient is a statistical device used to gauge the income distribution within a given nation.

${ }^{7}$ Lehman Brothers collapsed in September 2008 in on the back of huge losses accruing from the subprime mortgage crisis.

${ }^{8}$ Northern Rock was taken into 'temporary public ownership' in February 2008.

${ }^{9}$ Mandelson became the European Union's Trade Commissioner in November 2004, returning to Westminster in October 2008.

${ }^{10}$ Hills, Inequality and the State.

${ }^{11}$ Hills et al., Towards a More Equal Society.

${ }^{12}$ Ibid.

${ }^{13}$ Ibid.

${ }^{14}$ The Labour Party lost $80 \%$ of its seats in 1931, wining just 46 seats compared to 470 for the Conservatives.

${ }^{15}$ Minkin, The Contentious Alliance.

${ }^{16}$ Shaw, The Labour Party since 1979, pp.57-59.

${ }^{17}$ Young, This Blessed Plot.

${ }^{18}$ See Daddow, '"Tony's War"?'.

${ }^{19}$ Wright had served as Assistant Director of MI5 and the publication of his book was extremely controversial, see Spycatcher.

${ }^{20}$ Brown, speech to Labour Party conference, 2003.

${ }^{21}$ Liddle, The Europe Dilemma, p.92.

${ }^{22}$ Blair, 'Doctrine of the International Community' speech. 